\title{
SESENTA AÑOS \\ DE ENSEÑANZA Y EDUCACIÓN
}

Julián Meza*

¿Dónde está la sabiduría que perdimos con el conocimiento?

¿Dónde está el conocimiento que perdimos con la información?

T. S. Elliot

Vale más una cabeza bien puesta que una cabeza repleta.

Michel de Montaigne

Cuanto más poderosa es la inteligencia general, mayor es la facultad para analizar problemas especificos.

Edgar Morin

$\mathbf{P}_{\text {ara celebrar los sesenta años de }}$ vida del ITAM se ha decidido incluir en este número extraordinario de la revista Estudios únicamente contribuciones de profesores, alumnos y exalumnos del ITAM.

Una de las áreas fundamentales de enseñanza en el ITAM ha sido, desde el principio, la economía. Por enseñanza entiendo la acción de transmitir al alumno conocimientos de manera que los comprenda y los asimile.

La espina dorsal del ITAM han sido, también desde sus orígenes, los Estudios Generales, donde surgió esta revista hace poco más de veinte años. A diferencia de la enseñanza, la educación es, creo yo, el

* Departamento Académico de Estudios Generales, ITAM. 
despliegue de todos los medios necesarios y convenientes para asegurar la formación y el desarrollo de seres humanos con autonomía de pensamiento.

Tanto la enseñanza como la educación han cumplido sus cometidos en el ITAM, aun cuando no siempre hayan caminado de la mano.

Dado el estado actual del mundo, en donde no prevalece la crisis, sino el desorden, producido en buena medida por la hiperespecialización, me remito a una idea de Hayek, citada por Edgar Morin en La cabeza bien puesta, sólo para recordar la necesidad de la relación de la enseñanza con la educación: "Nadie que sea sólo un economista puede ser un gran economista." A esta frase añade algo digno de ser destacado por proceder de una autoridad intelectual como él: "un economista que no es más que un economista se convierte en alguien perjudicial y puede constituir un grave peligro".

Estoy convencido de que los Estudios Generales en el ITAM han contribuido en buena medida a atenuar los peligros de los que habla Hayek.

No es curioso que sea precisamente este economista el que me permita tender los puentes entre la enseñanza y la educación, dado que se trata de un heredero de la gran cultura austriaca, en donde no existió el supuesto conflicto entre las ciencias y las humanidades.

Desde un punto de vista que no es ajeno al de Hayek, celebro sesenta años de existencia del ITAM pues es grato saber que un gran economista como él se halle tan próximo a las humanidades como éstas a la economía.

Es por lo menos extraño que en un mundo globalizado y, por lo tanto, cada vez más complejo, se pueda creer que la mejor herramienta para entenderlo es la especialización. Globalización quiere decir, contrariamente a lo que por lo común se cree, mayor complejidad, y no ascenso de la simplificación, y por esto mismo se necesita cada vez más de una sabiduría que permita el mejor manejo de los conocimientos y, sobre todo, de la información. 